\title{
"The effect of risk leverage on investors' preferences in manufacturing companies listed on the Indonesia Stock Exchange"
}

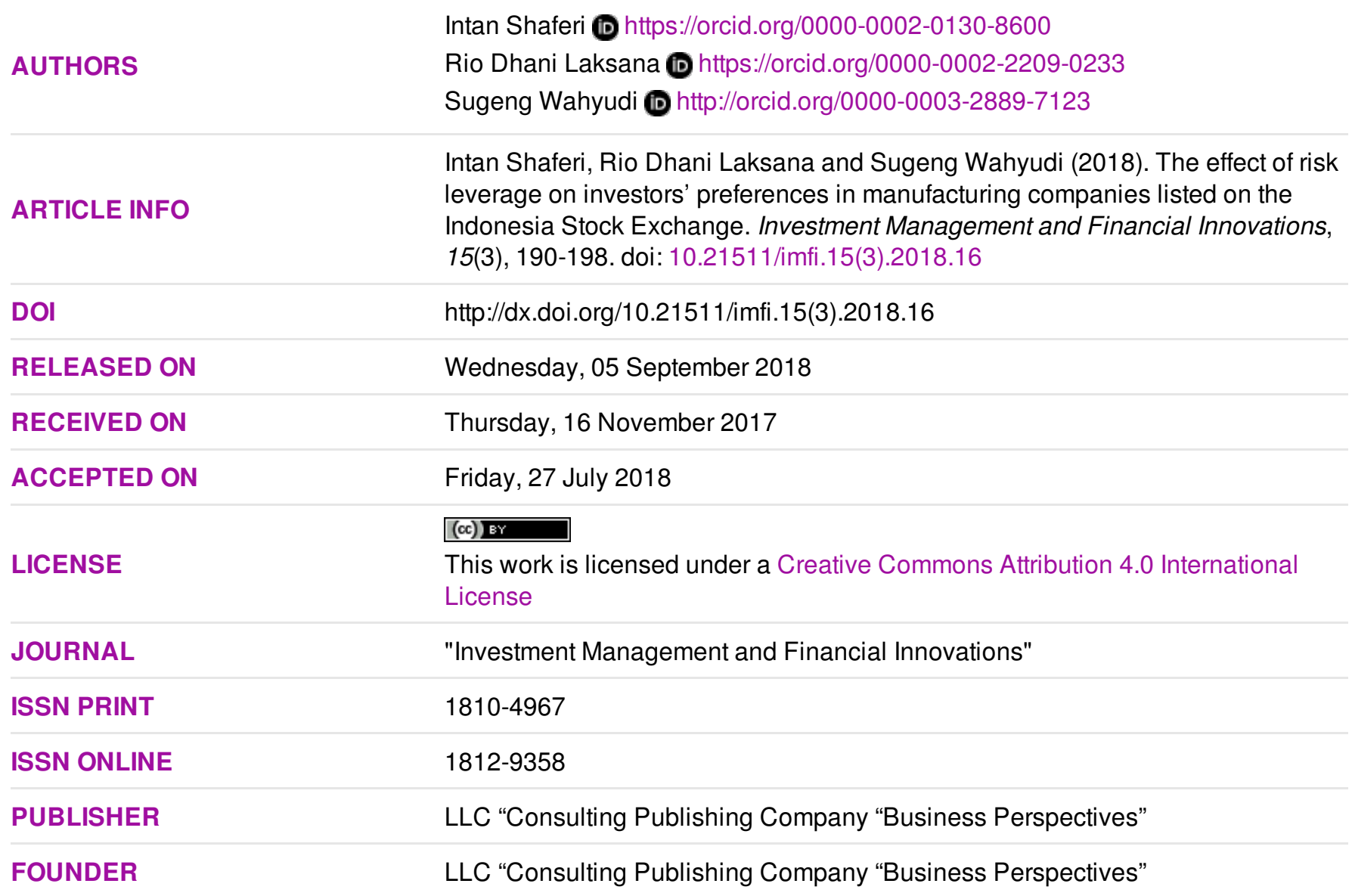

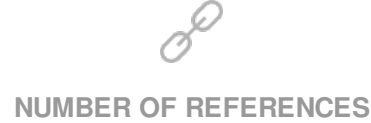

26
NUMBER OF FIGURES

2
ニ:ニ

NUMBER OF TABLES

3

(c) The author(s) 2023. This publication is an open access article. 


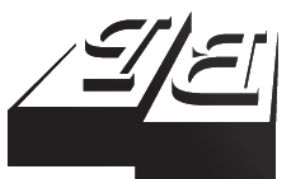

BUSINESS PERSPECTIVES

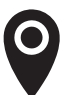

LLC "CPC "Business Perspectives” Hryhorii Skovoroda lane, 10, Sumy, 40022, Ukraine

www.businessperspectives.org

Received on: $16^{\text {th }}$ of November, 2017 Accepted on: $27^{\text {th }}$ of July, 2018

(C) Intan Shaferi, Rio Dhani Laksana, Sugeng Wahyudi, 2018

Intan Shaferi, Ph.D. Student at the Faculty of Economics and Business, Diponegoro University, Indonesia; Lecturer at the Faculty of Economics and Business, Jenderal Soedirman University, Indonesia.

Rio Dhani Laksana, Lecturer at the Faculty of Economics and Business, Jenderal Soedirman University, Indonesia.

Sugeng Wahyudi, Lecturer at the Faculty of Economics and Business, Diponegoro University, Indonesia.

\section{(ㄷ)(i)}

This is an Open Access article, distributed under the terms of the Creative Commons Attribution 4.0 International license, which permits unrestricted re-use, distribution, and reproduction in any medium provided the original work is properly cited.
Intan Shaferi (Indonesia), Rio Dhani Laksana (Indonesia),

Sugeng Wahyudi (Indonesia)

\begin{abstract}
Financial resources have become one of the funding policies considered by companies. The financial resources can come from internal and external sources. Leverage is used as one of the policies to get external source of funds. By using leverage, companies have additional funds that can be used for their operations and investments. When a company decided to use leverage as a financing policy, it is expected to get enough funds to finance its business. Raising the funds will lead to better company's financial performance. However, on the other hand, by raising funds, the company also needs to consider the risks. Thus, leverage is related to risk. Then, risk is one of the considerations for investors to think about.

This research aims to examine the effect of risk leverage and hopefully can give illustration for investors in analyzing the risks of investors' preferences. Besides, other variables used are size and profitability. These two variables are also the ground for considering risks. With pooled data analysis, this research was conducted on manufacturing companies listed on the Indonesia Stock Exchange during the five-year period from 2012 until 2016. The result shows that leverage, profitability and size have significant effects on risk.
\end{abstract}

Keywords

JEL Classification risk, leverage, size, profitability, manufacturing company

G10, G11, G19

\section{INTRODUCTION}

Every company management must set financial policies. The financial management allocates the existing funds and seeks the funding sources. The funding sources have become very important, because companies cannot work without this type of capital.

The financial resources have become one of the funding policies considered by the companies. Every company tends to have this kind of policy to provide the activities that will accomplish their target in succeeding their performance especially. A company, either in the form of services or manufacturers, refers to a certain specific policy, in which a funding policy with debt will be taken if it suits the company's needs. The service companies and manufacturers should greatly consider their sources of funding. The financial resources can come from internal and external sources. The internal sources of the company are from the retained earnings and the external sources can be debt and securities issuance. Thus, leverage becomes an urgent policy for company to decide if it needs the external sources of funds. 
The financial leverage indicates how much the operations of the company are financed with debt (Puspitaningtyas, 2017). When a company decides to use debt, it is expected to get enough funds to finance its business. Thus, the company will be able to operate maximally and earn the expected profit. These benefits can be seen from the performance of the company, especially from its financial performance. There are many studies that have discussed the work performance related to debt. In addition to the work performance, risks existing in the company can also be observed (Ahmad \& Qais, 2017). Investors with knowledge on the relationship between leverage and risks will be helpful in determining the risks of the company's stock on the capital market (Akbari \& Mohammadi, 2013).

Debt is related to risks. Several previous studies have provided these results (Ahmad \& Qais, 2017; Akbari \& Mohammadi, 2013; Bhatti et al., 2010; Dunn, 2001; Puspitaningtyas, 2017; Rashid, 2014). There is a correlation between debt and risks, where the higher the debt, the higher the risks. Leverage has a positive correlation with the systematic risk (Ahmad \& Qais, 2017; Bhatti et al., 2010; Dunn, 2001). To consider risks, work performance is important to discuss. Due to the debt, the risks of the company increase. Nevertheless, there are some previous studies, which suggest the other options that leverage has no significant effect on risks (Akbari \& Mohammadi, 2013). Furthermore, Khoshkar (2008) stated that financing through leverage has a considerable effect on the systematic risk, and so does the size of the company to risks.

Some previous studies relatively showed the performance and leverage, while this research is different in that it examines the risk and its relation with risk. In this field of research, capital market is used as a place that has a complex factor influence by micro and macro factors. One of the developing capital markets is Indonesia Stock Exchange. In this capital market, manufacturing is chosen because of its number of companies. This research aims to find out the effect of risk leverage on investors' preferences in manufacturing companies listed on the Indonesia Stock Exchange.

\section{LITERATURE REVIEW AND HYPOTHESES}

Leverage is one of policies related to capital structure of a company. Based on capital structure, pecking order theory (Myers, 1977) shows that a company will first utilize the internal source of funding before deciding to use the external sources. Internal source is the retained earnings, while the external source is debt or leverage before equity. In this research, leverage is used. What is then the effect of risks on a company, because usually only effects, which lead to performance, are studied, as mostly did by many researchers. But in this research, risk is used as the effect on the leverage selected. From risk, quadrant is made as a part of points of view by the investors' preferences that distinguishes this research from others.

Pecking order theory came from the information asymmetry. The information asymmetry indicates that managers have more information about the company than the investors. Thus, it will influence the decision of choosing whether to use inter- nal or external funding. Then, the internal should be first concern of funding.

Internal funding is used first, after it is no longer available, then, debt is issued, and when the debt is too big and has no sense anymore, then equity is issued. The theory prefers internal source if available, and debt is preferred over equity (which means issuing shares, which means bringing external ownership to the company). Thus, the debt provides a signal of external needs.

Pecking order theory was popularized by Myers and Majluf (1984). They argue that equity is a disadvantageous means of raising capital. It is because when managers issue new equities, investors believe managers think that the company is overvalued, and managers are taking advantage of this overvaluation condition. Then, investors will take a lower value for the issuance of new equities.

The funding decision is about the decision from which the financial source originated. In general, for large companies, both within and outside the 
company, there are advantages and disadvantages of each. Therefore, if the company is held by managers in the management, it allows agency conflict between owners and managers, because the owner will want as much wealth as possible, while the manager has his own wish that his decision can be against the owner's wishes.

Leverage is usually a description of how much money is borrowed for an investment and the company with high leverage is riskier (Stephan \& Alexander, 2015). Operating leverage positively affects the market risks (Lev, 1974). Leverage and counting beta are directly related to the systematic risks (Bowman, 1979).

Several previous studies have tested leverage toward risks. In a research conducted in a company in Pakistan (Bhatti et al., 2010), there were eight sectors studied using quantitative methods with mathematical technique. The results show that some sectors are below the average of industry leverage, such as fuel and energy, sugar, and allied industries. Transportation and communication, as well as engineering leverage are above the average. Based on the leverage effect, the reduction of equity will increase the debt to fix liabilities ratio so that it will increase the risks of the company.

The other research was conducted in leverage ratio consisting of operating leverage, financial leverage, compound leverage toward the systematic risks or beta (Akbari \& Mohammadi, 2013). In the study, there were one hundred and fifteen companies in Tehran Stock Market for eight years and they were analyzed with regression analysis and Pearson correlation. The result shows no significant correlation between the variables.

Tobin (1957) mentions the traditional theory relating risk and rate of return assumes that most stockholders are "risk averters" and therefore they require a higher return, a "risk premium", for taking on more risk (Hurdle, 1974). Further, financial risk is risk to stockholders based on the debt to equity ratio. Presumably, the risk of default is a function of the size of the fixed interest obligations relative to equity. The second type of risk, business risk, depends on the industry in which the firm operates. Gale argues that there is an optimum leverage level for each industry risk class
(Hurdle, 1974). There are two major hypotheses concerning risk and debt, first, risk premium high risk leads to high rate of return, and second, debt which requires low business risk, but causes large financial risk.

Another study also examined the role of the systematic risks in the capital market, where risks and return were the core of the research (Stephan \& Alexander, 2015). The research was conducted toward risks and return in real estate in Europe. This research examined the systematic risks correlation with market, size, $\mathrm{BE} / \mathrm{ME}$, and liquidity for ten years. The result shows that size and liquidity have significant relevance to real estate in Europe.

Further, a study was conducted toward the debt financing and risks in companies in Jordan (Khasawneh \& Dasouqi, 2017). The result shows that debt financing has a significant positive correlation to the systematic risks. Generally, risks are determined by some sources of uncertainty (Stephan \& Alexander, 2015). Furthermore, some risks to the organization are determined by size, complexity of business activity, volume, etc. (Laksana R. D. et al., 2017). Risk factors are related to market (MRP), size (SMB), and BE/ME (HML), which are derived from the general capital (Fama \& French, 1993). The systematic risks generally apply in assets or liabilities (Stephan \& Alexander, 2015). The systematic risk that can be measured by beta is how the company's stock is related to all securities in the capital market (Stephan \& Alexander, 2015). A positive beta will move along with the market movements. Other researches also use beta as a measurement for risk (Houmes, 2012).

Based on some of the previous studies, leverage has correlation with profitability and risk. Profitability which is measured by return on assets describes the earning from invested capital (Khasawneh \& Dasouqi, 2017). The return on assets shows the management efficiency of the enterprise's assets and is also a positive measure of firm value (Chen \& Chen, 2011). Therefore, it gives an idea to see an efficient management on using assets to create profit and higher return on assets that will lead to higher systematic risk. Saritas (2000) suggests that any increase of operating leverage will increase the profitability of the company that will lead to increase in risk. 
Pecking order theory assumes that when a company has a need for capital, it will first consider the reserve surplus, and then debt, and the last choice is issuing new shares. Myers (1984) argues from asymmetry information perspective, by issuing new shares, it will make a decline in stock price, which will cause an equity agency cost. Thus, the issuing of new shares is the last choice. A company with high profitability will not depend on the external funding, because profitability has a negative effect on leverage (Chen \& Chen, 2011).

Then size has relatively a positive effect on risk. A previous study used natural logarithm of assets to measure the size, with risk as a dependent variable and beta as a measurement tool (Houmes, 2012). Firm size will determine its leverage (Hol \& Wijst, 2008). According to Panno (2003) and Ojah and Manrique (2005), when firms have the same profitability, the larger firm will have a relatively low level of debt (Chen \& Chen, 2011).

Hypotheses for this research based on theories and previous researches are:

H1: There is a significant relationship between leverage and risk.

H2: There is a significant relationship between profitability and risk.

H3: There is a significant relationship between size and risk.

\section{METHODOLOGY}

This research was conducted in the manufacturing companies listed on the Indonesia Stock Exchange (IDX). Manufacturing is one sector that has high probability potential for success from time to time as indicated by list of companies in IDX where the number of manufacturing companies increases. The data source was from Bloomberg, with research period from 2012 to 2016 or within five years. The research used 320 data taken from 64 manufacturing companies for five-year research period.

This research was conducted with dependent and independent variables. The dependent variables were risks measured by beta and the independent ones comprise leverage, profitability, and firm size.

This research used proxy beta as the systematic risks, while some previous researches used proxy beta as its measurement (Ahmad \& Qais, 2017; Akbari \& Mohammadi, 2013; Bhatti et al., 2010; Dunn, 2001). Meanwhile, the independent variables, leverage used debt to total assets (Nadarajah et al., 2016). Then, size used total assets as the company size, and profitability used return on assets. The use of return on assets means how the company will get the net income from its assets. If the value is high, then it would lead to the less risk from the companies because they need to pay the leverage obligation.

The analysis method of this research was the pooled data regression using EViews. The advanced analysis was the quadrant division descriptively in order to review the future estimation.

\section{EMPIRICAL RESULTS AND DISCUSSIONS}

This research used 320 data from 64 manufacturing companies listed on the Indonesia Stock Exchange for five years to test the risk variable and leverage, profitability, and company size. The dependent variable of risk was measured by beta. The independent variable was the leverage that was calculated by debt to total assets ratio. It was a ratio between the total debt and the total assets. Profitability was measured by the return on assets that the net income was divided by total assets, and size was measured by the assets. It was the natural logarithm of assets.

Using pooled regression analysis, the result showed that each variable is significant to dependent variables which mean risk. Result for regression is illustrated in Table 1.

Next, the F-test was performed by the model accuracy test. F-statistic was 30.58224 , where the critical $\mathrm{F}$ was 3.02 and significant at 5\%. Thus, the F-statistic was greater than the critical F. The probability value was 0.00 . Hence, the conclusion was that the independent variables in the regression model, together, significantly influenced the risks variable as the dependent variable. 
Table 1. Regression output

\begin{tabular}{|c|c|c|c|c|}
\hline Variable & Coefficient & Std. Error & t-statistic & Prob. \\
\hline DAR & -0.002104 & 0.000933 & -2.255563 & 0.0248 \\
\hline ROA & 0.005342 & 0.001961 & 2.724403 & 0.0068 \\
\hline SIZE & 0.075738 & 0.010500 & 7.213252 & 0.0000 \\
\hline C & -1.437464 & 0.297445 & -4.832704 & 0.0000 \\
\hline R-squared & 0.225009 & \multicolumn{2}{|c|}{ Mean dependent variable } & 0.696272 \\
\hline Adjusted R-squared & 0.217652 & \multicolumn{2}{|c|}{ S. D. dependent variable } & 0.306595 \\
\hline S. E. of regression & 0.271185 & \multicolumn{2}{|c|}{ Akaike info criterion } & 0.240389 \\
\hline Sum squared residual & 23.23902 & \multicolumn{2}{|c|}{ Schwarz criterion } & 0.287493 \\
\hline Log likelihood & -34.46224 & \multicolumn{2}{|c|}{ Hannan-Quinn criterion } & 0.259199 \\
\hline F-statistic & 30.58224 & \multicolumn{2}{|c|}{ Durbin-Watson statistics } & 1.180219 \\
\hline Prob. (F-statistic) & 0.000000 & & & \\
\hline
\end{tabular}

Note: Risk - beta; DAR - debt to assets ratio; $R O A$ - return on assets; SIZE - firm size; $C$ - constanta.

To find the effect of each independent variable to dependent variable, $t$-test was performed. The $t$ test showed that the statistical $t$-value was greater than the critical t-value. It means that the variables of DAR, ROA, and SIZE had significant effects on the risks variable.

Based on the result of regression, the regression equation is as follows:

$$
\begin{aligned}
& \text { Risk }=-1.4370 .002 D A R+ \\
& +0.005 \text { ROA }+0.075 \text { SIZE }+e,
\end{aligned}
$$

where Risk - beta, $D A R$ - debt to assets ratio, ROA - return on assets, SIZE - firm size.

It means that leverage had a negative correlation to risks. Due to the change on leverage, the coefficient value -0.002 would change to 0.002 to risks. It means, when the company has high debt, the risk is also high. The coefficient value 0.005 on the return on assets would result in a change of 0.005 to risks. Moreover, the SIZE gave an effect 0.075 to risks.

The result of size showed that size had a significant positive effect toward risks. It supported the previous research which stated that size had a positive effect on risks (Akbari \& Mohammadi, 2013). Leverage had a negative effect on return on assets.

This result accepted $H 1$ that leverage had effect on risk. When a company used higher leverage, the optimist side was an opportunity to expand and improve the company to have a better perfor- mance including the higher profit; hence, it will lead the company to accomplish the obligation of leverage. Thus, the result for $\mathrm{H} 2$ that profitability had effect to risk was accepted. Similarly, the third hypothesis that size affects risk was also accepted. The bigger company will lead to the use of higher leverage, because in this position the company had access to use higher leverage and will lead to higher risk.

Table 1 shows the results that the regression could be performed with the passed results for the classical assumption test including normality test, autocorrelation test, and heteroscedasticity test. Model fit and the independent variables were significant to the dependent variables. For the classical assumption test, the normality test was performed. The results are in Figure 1.

The normality test showed a probability value 0.01 below 0.05 , which indicated a normal distribution. This normality indicates that the analysis can be conducted by using the data. Then, the results of the autocorrelation test were shown in Table 2. The results of the test illustrated the value of VIF and TOL. The data show that VIF was 1.36986301 and TOL was 0.73 . There was no autocorrelation, because the VIF value was less than 10 and the TOL value was not more than one. Autocorrelation test is used to test the correlation intervariable. Then, the result showed that there was no correlation. It means that the research can be conducted using all the variables.

The heteroscedasticity test showed the following results. 


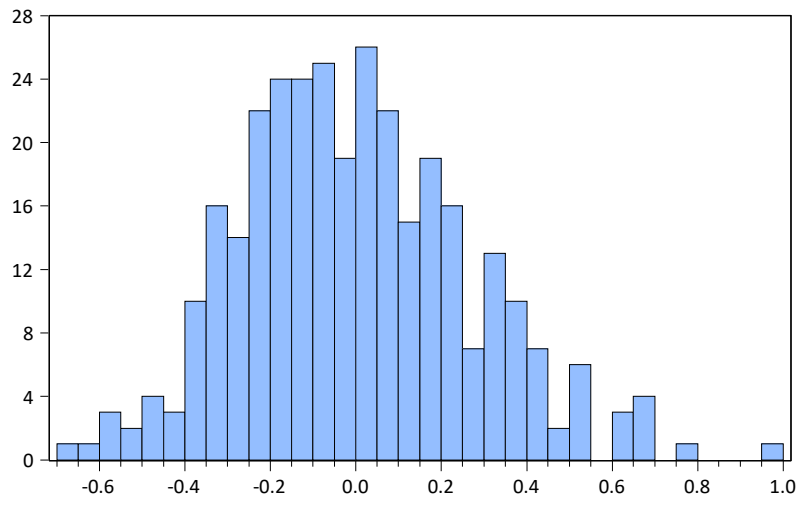

$\begin{array}{ll}\text { Series: } & \text { Standardized Residuals } \\ \text { Sample } & 20122016 \\ \text { Observations } & 320 \\ \text { Mean } & 4.44 \mathrm{e}-16 \\ \text { Median } & -0.017109 \\ \text { Maximum } & 0.994165 \\ \text { Minimum } & -0.673522 \\ \text { Std. Dev } & 0.269907 \\ \text { Skewness } & 0.396163 \\ \text { Kurtosis } & 3.229547 \\ \text { Jarque-Bera } & 9.072973 \\ \text { Probability } & 0.010711\end{array}$

Figure 1. Normality test

Table 2. Autocorrelation test

\begin{tabular}{|c|c|c|c|c|}
\hline Variable & Coefficient & Std. Error & t-statistic & Prob. \\
\hline $\mathrm{ROA}$ & -1.106318 & 0.100391 & -11.02014 & 0.0000 \\
\hline SIZE & 1.667982 & 0.625193 & 2.667949 & 0.0080 \\
\hline C & -11.51424 & 17.89683 & -0.643368 & 0.5205 \\
\hline R-squared & 0.277223 & \multicolumn{2}{|c|}{ Mean dependent variable } & 31.45014 \\
\hline Adjusted R-squared & 0.272663 & \multicolumn{2}{|c|}{ S. D. dependent variable } & 19.14477 \\
\hline S. E. of regression & 16.32743 & \multicolumn{2}{|c|}{ Akaike info criterion } & 8.432901 \\
\hline Sum squared residual & 84507.45 & \multicolumn{2}{|l|}{ Schwarz criterion } & 8.468229 \\
\hline Log likelihood & -1346.264 & \multicolumn{2}{|c|}{ Hannan-Quinn criterion } & 8.447008 \\
\hline F-statistic & 60.79321 & \multicolumn{2}{|c|}{ Durbin-Watson statistics } & 0.730523 \\
\hline Prob. (F-statistic) & 0.000000 & & & \\
\hline
\end{tabular}

T was critical at $5 \%$. It was 1.65251 , and t-statistics of all independent variables were less than critical $t$, so there was no heteroscedasticity occurred. Thus, it passed the classical assumption test.

Furthermore, it is important to see the test results on the coefficient of determination to determine the effect of variables of $D A R, R O A$, and SIZE on risks. R-square found in this research was 0.225 or it means $22.5 \%$ of risks variable. They were de- termined by the variables of $D A R, R O A$ and SIZE; and the rest was determined by other factors outside this research.

Besides knowing the relationship, to describe the risk in manufacturing sector can be seen in Figure 2. Risks that can be described from the manufacturing sector on the Indonesia Stock Exchange are that companies with leverage are average with the risks in it.

Table 3. Heteroscedasticity test

\begin{tabular}{|c|c|c|c|c|}
\hline Variable & Coefficient & Std. Error & t-statistic & Prob. \\
\hline RISK & 0.110512 & 0.032893 & 3.359712 & 0.0009 \\
\hline DAR & -0.000542 & 0.000550 & -0.984851 & 0.3255 \\
\hline ROA & 0.001255 & 0.001160 & 1.081468 & 0.2803 \\
\hline SIZE & 0.001959 & 0.006626 & 0.295735 & 0.7676 \\
\hline C & 0.092345 & 0.180236 & 0.512357 & 0.6088 \\
\hline R-squared & 0.074731 & \multicolumn{2}{|c|}{ Mean dependent variable } & 0.214177 \\
\hline Adjusted R-squared & 0.062982 & \multicolumn{2}{|c|}{ S.D. dependent variable } & 0.163810 \\
\hline S.E. of regression & 0.158568 & \multicolumn{2}{|c|}{ Akaike info criterion } & -0.829765 \\
\hline Sum squared residual & 7.920302 & \multicolumn{2}{|l|}{ Schwarz criterion } & -0.770885 \\
\hline Log likelihood & 137.7623 & \multicolumn{2}{|c|}{ Hannan-Quinn criterion } & -0.806253 \\
\hline F-statistic & 6.360421 & \multicolumn{2}{|c|}{ Durbin-Watson statistics } & 1.618205 \\
\hline Prob. (F-statistic) & 0.000062 & & & \\
\hline
\end{tabular}




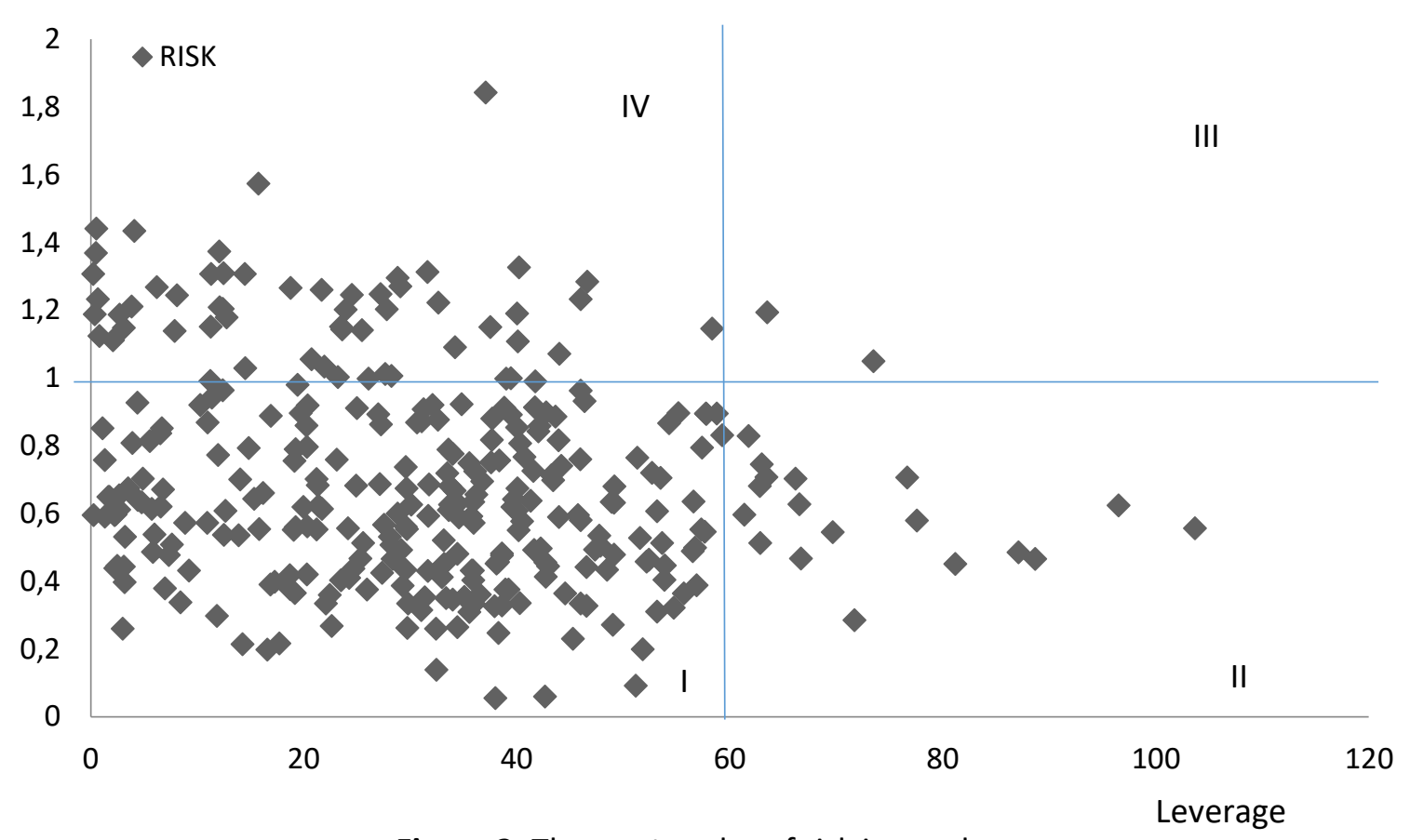

Figure 2. The scatter plot of risk in quadrant

From the scatter plot of each manufacturing company, it can be seen that manufacturing companies listed on the Indonesia Stock Exchange were distributed as average. From all companies, almost eighty per cent were at the average level between leverage and risk. From the result, all parties are supposed to consider the company's leverage.

Investors tend to choose a company for their funds from each preference. If investors choose the less risky investment, they are risk averse and most investors are indeed risk averse, and certainly the average investors are risk averse with regard to their serious money (Brigham, 2010). But if investors take more risks, they are risk takers. Figure 2 for quadrant of risk shows quadrant with each preference.
Based on the figure, an investor who is a risk averter will be at companies in quadrant 1, because it has less risk in less leverage. Quadrant II has less risk and high leverage. Some companies in this quadrant take leverage so the investor could be a risk taker. Almost the same in quadrant III, the investor takes companies with high leverage. The last, the riskier group, is quadrant IV, with less leverage but it has high risk than the other companies' average.

This describes how investor preferences will take the risk on the stock exchange especially in the Indonesia Stock Exchange, focusing on manufacturing companies. Future research can make it complete by deeper research for each sub-sector.

\section{CONCLUSION AND FUTURE RESEARCH}

This research has tested leverage toward risks and has used other variables, such as profitability and size. Risks to companies are very important to consider, and factors that affect the risk in this research are $D A R, R O A$, and SIZE. Investors will have different perspective to the risks if the company used leverage. Therefore, leverage has an effect on risk and will lead investor to choose a company. Thus, it makes the companies concern about the risk faced because of the use of leverage.

It is suggested that future researches can give detail about the sector of manufacture and use more variables that have relationship to risk. Besides, other variables could be from external factors and macroeconomic factors. Those will make the research complete. 


\section{IMPLICATION}

This research examines the leverage towards the risk on the Indonesia Stock Exchange. The research attempts to describe the leverage of the firm that effects the risk. This could be used as a reference for the investors who will invest their fund. It gives information that, besides profitability, there are risks which can be considered when investing fund, especially in manufacturing companies. Some studies may give clue and description related to leverage effect on the firm's value or firm's profitability. However, in this research, leverage and risk are examined.

\section{RESEARCH LIMITATION}

This research aims to examine the leverage towards risk. It explores the risk side as a dependent variable where several studies explain about the profitability as a dependent variable. Thus, this study still has limited variables. Related to this limitation, next researches could use more independent variables and complex sector, not only manufacturing.

\section{REFERENCES}

1. Ahmad, Y. K., \& Qais, A. D. (2017). Sales nationality and debt financing impact on firm's performance and risk: Evidence from Jordanian companies. EuroMed Journal of Business, 12(1), 103-126. http://dx.doi. org/10.1108/EMJB-05-2016-0015

2. Akbari, P., \& Mohammadi, E. (2013). A study of the effects of leverages ratio on systematic risk based on the capital asset pricing model among accepted companies in Tehran stock market. http://dx.doi.org/10.5267/j. msl.2013.01.020

3. Bhatti, A. M., Majeed, K., Rehman, I., \& Khan, W. (2010). Affect of leverage on risk and stock returns: evidence from Pakistani companies. International Research Journal of Finance and Economics, 58, 32-49.

4. Bowman, R. G. (1979). The theoretical relationship between systematic risk and financial (accounting) variables. The Journal of Finance, 34(3), 617-630

5. Brigham, E. F., \& Ehrhardt, M. C. (2010). Financial Management: Theory and Practice. Thomson ONE Publishers.

6. Chen, L.-J., \& Chen, S.-Y. (2011). The influence of profitability on firm value with capital structure as the mediator and firm size and industry as moderators. Investment Management and Financial Innovations, 8(3), 121-129.

7. Dunn, M. F. (2001). An intuitive interpretation of beta. Proceeding at the Allied Academies International Conference Academy for Economics and Economic Education.

8. Houmes, R. E., MacArthur, J. B., \& Harriet, S. (2012). The operating leverage impact on systematic risk within a context of choice: An analysis of the US trucking industry. Managerial Finance, 38(12), 1184-1202. http://doi. org/10.1108/03074351211271283

9. Fama, E. F., \& French, K. R. (1993). Common risk factors in the returns on stocks and bonds. Journal of Financial Economics, 33(1), 3-56.

10. Hol, S., \& Wijst, N. V. (2008). The financial structure of nonlisted firms. Applied Financial Economics, 18(7), 559-568.

11. Hurdle, G. J. (1974). Leverage, risk, market structure and profitability. The Review of Economics and Statistics, 56, 478-485.

12. Khasawneh, A. Y., \& Dasouqi, Q. A. (2017). Sales nationality and debt financing impact on firm's performance and risk: Evidence from Jordanian companies. EuroMed Journal of Business, 12(1),
103-126. http://doi.org/10.1108/ emjb-05-2016-0015

13. Khoshkar Hassan Kyadeh, F. (2008). Investigate the relationship between financial and operating leverages with systematic risk (beta) in companies Listed in Tehran Stock Exchange (Master thesis of banking institutions in Iran). Retrieved from www.ibi. ac.ir/files/DataViewComplete. Php?PCODEX=293

14. Laksana, R. D., Hersugondo, H., Wahyudi, S., Muharam, H. (2017). The new decomposition asset growth effect. An empirical evidence of Indonesia. Journal of Applied Economic Sciences 12(4), 977-984. Retrieved from http:// cesmaa.org/Docs/JAES\%20Summer\%20XII\%204(50)2017_online.pdf

15. Lev, B. (1974). On the association between operating leverage and risk. Journal of financial and quantitative analysis, 9(4), 627-641.

16. Myers, S. C. (1977). Determinants of corporate borrowing. Journal of Financial Economics, 5(2), 147-175. http://dx.doi.org/10.1016/0304405X(77)90015-0

17. Myers, S. C. (1984). The capital structure puzzle. The Journal of Finance, 39(3).

18. Myers, S. C., \& Maljuf, N. S. (1984). Corporate Financing 
And Investment Decisions When Firms Have Information That Investors Do Not Have. Journal of Financial Economics, 13, 187-221.

19. Nadarajah, S., Ali, S., Liu, B., \& Huang, A. (2016). Stock liquidity, corporate governance and leverage: New panel evidence. Pacific-Basin Finance Journal. https://doi.org/10.1016/j.pacfin.2016.11.004

20. Ojah, K., \& Manrique, J. (2005). Determinants of corporate debt structure in a privately dominated debt market: a study of the Spanish capital market. Applied Financial Economics, 15(7), 455-468. https://doi.org/10.1080/0960310042000319228
21. Panno, A. (2003). An empirical investigation on the determinants of capital structure: the UK and Italian experience. Applied financial economics, 13(2), 97-112. https://doi. org/10.1080/09603100210100882

22. Puspitaningtyas, Z. (2017). Estimating systematic risk for the best investment decisions on manufacturing company in Indonesia. Investment Management and Financial Innovations, 14(1), 46-54. http://dx.doi.org/10.21511/ imfi.14(1).2017.05

23. Rashid, A. (2014). Firm external financing decisions: explaining the role of risks. Managerial Finance, 40(1), 97-116. https://doi. org/10.1108/MF-02-2013-0049

24. Saritas, H. (2000). The impact of financial leverage on return and risk. Degrisi Journal, 15(1), 2334.

25. Stephan, L., \& Alexander, S. (2015). The diverging role of the systematic risk factors: evidence from real estate stock markets. Journal of Property Investment \& Finance, 33(1), 81-106. https://doi. org/10.1108/JPIF-05-2014-0032

26. Tobin, J. (1958). Liquidity preference as behavior towards risk. The Review Of Economic Studies, 25(2), 65-86. 